\title{
Lipophilization of flavonoids for their food, therapeutic and cosmetic applications
}

\author{
Martina Danihelováa, Jana Viskupičováa, ${ }^{\mathrm{a}, \mathrm{b}}$, Ernest Šturdík ${ }^{\mathrm{a}, \mathrm{c}}$ \\ ${ }^{a}$ Institute of Biochemistry, Nutrition and Health Protection, Faculty of Chemical and Food Technology, \\ Slovak University of Technology, SK-812 37 Bratislava \\ ${ }^{b}$ Institute of Experimental Pharmacology and Toxicology, Department of Biochemical Pharmacology, \\ Slovak Academy of Sciences, SK-841 04 Bratislava \\ ${ }^{c}$ Department of Biotechnology, Faculty of Natural Sciences, University Ss. Cyril and Metodius, \\ SK-91701 Trnava \\ martina.danihelova@stuba.sk
}

\begin{abstract}
Flavonoids represent large group of plant pigments. These polyphenolic compounds may be found in the nature as active components of fruits, vegetables and other plants and derived products. Due to established biological effects they are attractive substances for many areas of human life. Many flavonoids are nowadays used in pharmaceutical, cosmetic and food preparations. Their practical applications are in most cases limited by low solubility and stability in lipophilic media. Chemical or enzymatic lipophilization of flavonoid skeleton may not only increase their solubility and stability in lipophilic environment but also their biological properties. This review summarizes current knowledge in this field.
\end{abstract}

Keywords: biological activity, commercial applications, flavonoid, lipophilization

\section{Introduction}

Flavonoids as natural compounds of plant origin represent with their abundance the largest group of polyphenolic compounds. To-date, more than 8000 structures have been identified (Caballero, 2009). Their common natural sources are mainly different sorts of fruits, vegetables and cereals. In nature, they can exist as aglycons but more often they form glycosides (Lugasi et al., 2003).

Many studies have shown an inverse correlation between intake of food rich in flavonoids and a risk of cardiovascular, cancer and other diseases associated with ageing (Hertog et al., 1993; Knekt et al., 1997; Knekt et al., 2002; Mink et al., 2007; Kyle et al., 2010). Many works attributed their beneficial health effects to their ability to act as antioxidants. Among other documented effects, it may be underlined their antimicrobial, antiallergic, antiviral, hepatoprotective, anticancer, antiinflammatory, vasodilatory and gastroprotective action (Yao et al., 2004; Viskupičová et al., 2008; Prasain et al., 2010).

Several flavonoids are currently used in pharmaceutical, cosmetic and food preparations (Ardhaoui et al., 2004; Vorsa et al., 2007; Birbara, 2011). However, their usage is often limited due to low solubility and stability in lipophilic media. Therefore, preparation of lipophilic flavonoid esters via derivatization of their hydroxyl groups with hydrophobic molecules may be used as a tool for improvement of this limitation (Mellou et al., 2005; Viskupičová et al., 2009a; Viskupičová et al., 2009b).
This paper summarizes possibilities of chemical and enzymatic lipophilization of flavonoids with particular impact on biological activities of initial molecules. It also introduces the possibilities of practical applications of flavonoid derivatives.

\section{Flavonoid lipophilization}

Basic structure of most flavonoids is derived from 2-phenylbenzo- $\gamma$-pyran. Original skeleton contains numerous hydroxyl groups. An example represents one of the best known flavonoids quercetin (Fig. 1). Many flavonoids are found in nature especially as glycosides. Particular saccharide is mostly connected to the carbon atom in the position 3, 5 or 7 (Robards and Antolovich, 1997). By the attachment of rhamnoglucosyl to quercetin molecule, rutin is formed (Fig. 1). Numerous hydroxyl groups on a flavonoid molecule result in considerably hydrophilic nature of most flavonoids.

Frequently, flavonoid hydrophilicity makes a disadvantage for commercial applications when used in lipophilic food and cosmetic matrices, eventually on lipophilic cell membranes or after its penetration to specific target tissues. In such cases, the solution could be a chemical or enzymatic derivatization of hydroxyl groups with more lipophilic substituent. Our team (Viskupičová et al., 2009c) found that lipophilic esters of rutin are probably able to incorporate into the lipid bilayer of sarcoplasmic reticulum $\mathrm{Ca}^{2+}$-ATPase, cause changes in physico-chemical properties of the membrane and conformational modifications 
<smiles>O=c1c(O)c(-c2ccc(O)c(O)c2)oc2cc(O)cc(O)c12</smiles>

Quercetin

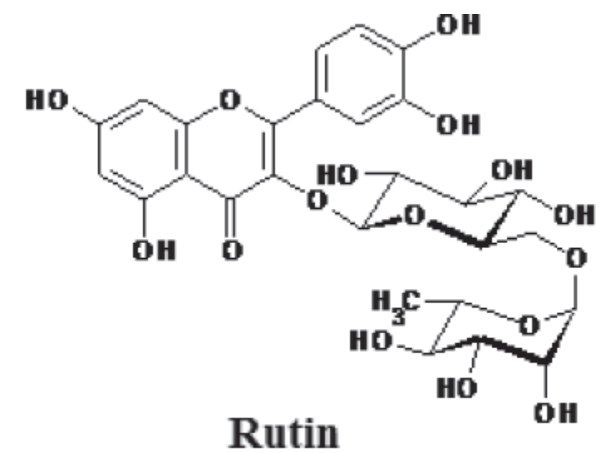

Rutin

Fig. 1. Polyhydroxylated structures of quercetin (left) and rutin (right).

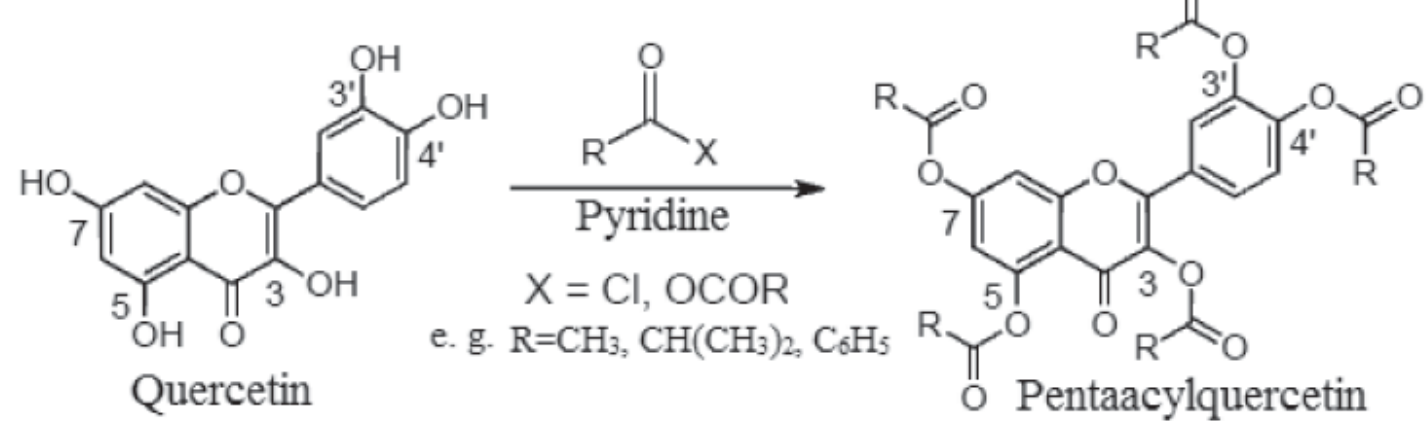

Fig. 2. Chemical synthesis of pentaacylquercetin (modified according Mattarei et al., 2010).<smiles></smiles><smiles>COc1cc(O)c2c(=O)c(OC)c(-c3ccc(O)c(O)c3)oc2c1</smiles>

Fig. 3. Synthesis of 4'-O-methylquercetin using protecting groups (Li et al., 2009).

of the enzyme, and thus inhibit $\mathrm{Ca}^{2+}$-ATPase activity, what may be helpful in apoptosis induction in antitumor therapy.

\section{Chemical modification}

Chemical approach in the synthesis of lipophilic flavonoid derivatives is non-selective (Fig. 2). It leads to the mixture of products with various numbers of linked substituents. The reaction must be often performed under severe reaction conditions, such as toxic media or high temperatures (Mattarei et al., 2010).

In chemical synthesis, one of the most frequently used methods is esterification (Fig. 2), particularly 
acetylation. By this approach, some reactive or all hydroxyl groups can be modified. Commonly used reaction substrates include acetyl chloride or acetic anhydride in pyridine or dimethyl formamide (DMF). However, selective esterification is often required to maintain antioxidant properties of initial flavonoids. Therefore, the connection of their molecules with non-polar groups is efficient solution in order to exert antioxidant effects in hydrophobic environment (Bridson, 2007).

To obtain mono-derivatives, it is necessary to use protecting groups for the rest of hydroxyl groups and thereafter to remove it. For example, for the synthesis of 4'-O-methylquercetin (yield $63 \%$ ) for selective protection of catechol group, dichloro diphenyl methane at $175{ }^{\circ} \mathrm{C}$ in diphenyl ether can be used and for protection of hydroxyl groups in the positions 3 and 7, chlormethyl ether is a suitable agent (Fig. 3) (Li et al., 2009).

Using Mannich reaction, it is possible to produce alkylamine derivatives. Products of the reaction of dihydroquercetin with formaldehyde and amines are mono- and diaminomethyl derivatives (Fig. 4) (Kukhareva et al., 2004).
Another often used method is alkylation. Using aldol condensation, alkyl and benzyl substituents can be added to the flavonoid molecule (van Aardt et al., 1998). Other feasible possibility provides Williams synthesis of ethers or alcoholysis of epoxides. Alkylation is often performed with alkyl halogenides (Fig. 5). In nature, some alkylated flavonoid derivatives can also be found, mainly derivatives with lower alcohols (Materska, 2008).

Simple ethers can be prepared from alkylene oxides. Penta- and tetrahydroxyethyl quercetin were obtained via alkylation with an excess of ethylene oxide in water under catalysis of potassium hydroxide (Fig. 6) (Bridson, 2007).

\section{Enzymatic derivatization}

Enzymes represent an efficient substitute to the standard chemical methods for the selective preparation of flavonoids. Enzymatic acylation of flavonoids may be performed either directly as esterification or transesterification (Fig. 7) (Chebil et al., 2006).

For flavonoid acylation in vitro, a wide range of hydrolytic enzymes have been used. These include

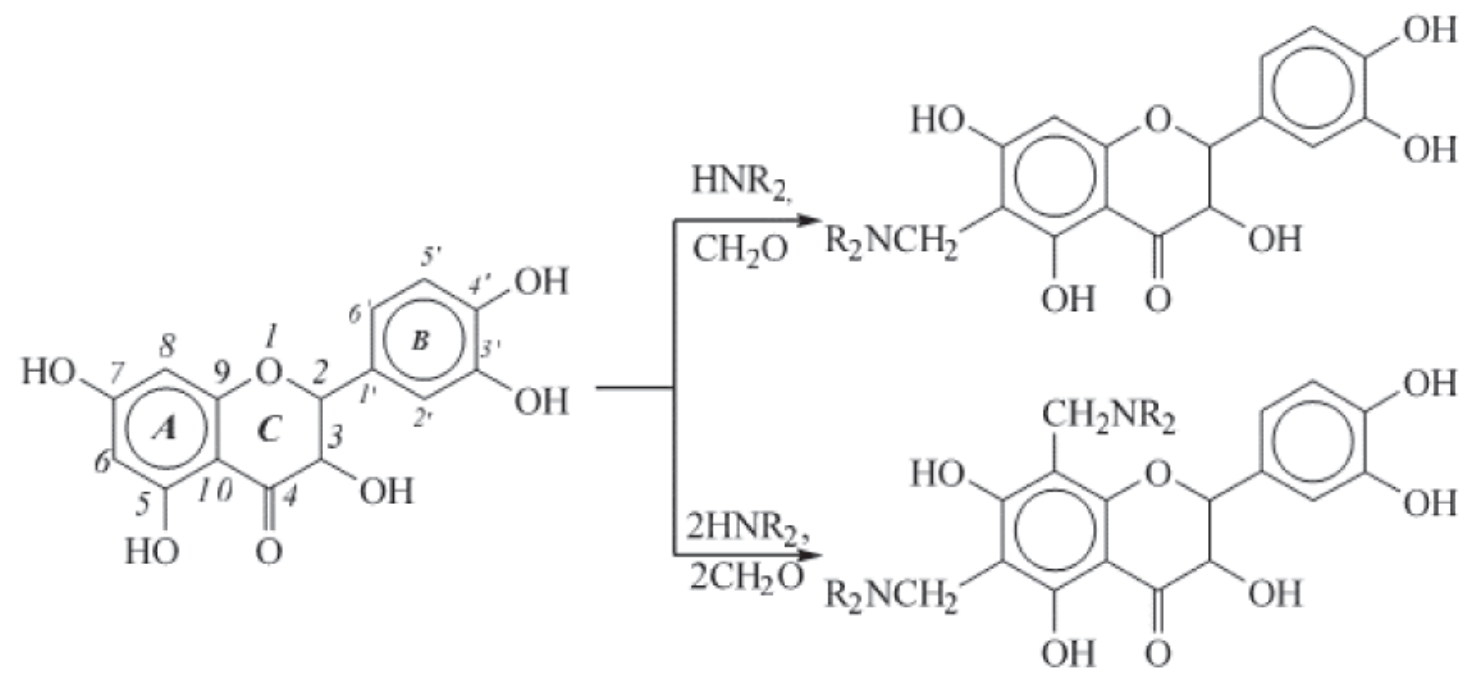

Fig. 4. Preparation of alkylamino derivatives of quercetin via Mannich reaction (Kukhareva et al., 2004).<smiles>O=c1c(O)c(-c2ccc(O)c(O)c2)oc2cc(O)cc(O)c12</smiles><smiles>CC(O)CCl</smiles>

<smiles></smiles>

$\mathrm{R}=\mathrm{H}, \mathrm{CH}_{2} \mathrm{CHOHCH}_{3}$

Fig. 5. Alkylation of quercetin with 1-chlorpropan-2-ol in DMF in the presence of potassium carbonate (Bridson, 2007). 
<smiles>[R20]Oc1cc(O[R2])c2c(=O)c(O[R2])c(-c3ccc(O[R])c(O[R2])c3)oc2c1</smiles>

Fig. 6. Preparation of hydroxypropyl ether of quercetin via treating with propylene oxide

(Bridson, 2007).<smiles>C=CCOC(=O)CCC</smiles>

Fig. 7. Enzymatic acylation of flavonoids: (a) esterification; (b) trans-esterification

(Chebil et al., 2006).


Fig. 8. The positions of esterification of studied flavonoids and flavonoid-related compounds by fatty acids of C4 to C22.

three basic groups, i.e. lipases, esterases and proteases. Among lipases, lipase B from Candida antarctica is most widely used enzyme which is able to catalyse reactions with many substrates, to tolerate various organic solvents and high temperatures (McCabe et al., 2005). Authors of up-to-date published papers performed enzymatic acylation of flavonoids in the range of reaction temperatures of $30-130{ }^{\circ} \mathrm{C}$. The most often used organic solvents are 2-methylpropan-2-ol,2-methylbutan2-ol, hexane, pyridine, acetone and acetonitrile.
Substituents introduced to the flavonoid molecule include both different fatty acids $\left(\mathrm{C}_{4}-\mathrm{C}_{20}\right)$ and aromatic acids, such as cinnamic, $p$-coumaric or caffeic acid, substituted or without substituents (Danieli et al., 1990; Gao et al., 2001; Kontogianni et al., 2003; Ardhaoui et al., 2004; Passicos et al., 2004; Mellou et al., 2005; Salem et al., 2010). Derivatization with aromatic acids is especially interesting because phenolic acids themselves exert interesting biological activities (Rice-Evans et al., 1996; Mudnic et al., 2010). 




Fig. 9. Correlation of mathematically predicted miLogP value with experimentally determined $R_{M}$ value of rutin and rutin esters $(r=0.993 . p<0.0001)$, symbols $\mathrm{R} 4-\mathrm{R} 18: 3$ refer to the individual rutin derivatives esterified with fatty acids of $\mathrm{C}_{4}-\mathrm{C}_{18}$ (Viskupičová et al., 2010).

Our team dealt with the preparation of derivatives of flavonoids (rutin) and flavonoid-related compounds (phloridzin, esculin) with fatty acids of various chain lengths (Viskupičová et al., 2010; Viskupičová et al, 2011). Exact position of acylation is outlined in the Fig. 8.

Measurements of lipophilicity of these derivatives showed that their lipophilicity parameters $R_{M}$ were really increased compared to basic molecules. This values were in good correlation with theoretical data (miLogP) predicted by the Molinspiration program (Fig. 9) (Viskupičová et al., 2010).

\section{Biological activities of lipophilic flavonoid derivatives}

The idea of flavonoid lipophilization is a matter of a last decade, with big expansion in last few years. Particular works revealed that through introducing lipophilic molecules to the basic flavonoid skeleton not only physico-chemical properties can be modified but also biological effects of flavonoids are improved. Table 1 provides an overview of selected up-to-date tested biological activities of lipophilic flavonoid derivatives.

Salas et al. (2011) tested antifungal activity of four flavonoids and their derivatives esterified with butyric, decanoic and lauric acid, isolated from citrus fruits. Experiments have shown that lipophilic derivatives more effectively inhibited growth of food contaminant micromycetes Aspergillus parasiticus, Aspergillus flavus, Fusarium semitectum and Penicillium expansum than original unmodified molecules. Methylated thiaflavanes effectively suppressed growth of many yeast microorganisms (Buzzini et al., 2008).
Sheng et al. (2009) prepared a series of nitrogen flavonoid derivatives. Most of them showed significant inhibitory effect on acetylcholine esterase activity. Among them, the most effective was the derivative containing pyrrolidine, which was more active than commercial medicament Dopenezil.

Lue et al. (2010) reported lowered ability of rutin laurate and rutin palmitate to bind metals and to prevent lipid oxidation compared to rutin; however these rutin esters more effectively protected LDL cholesterol from oxidation in vitro. Prunin esterification with aliphatic molecules slightly increased its antioxidant activity (Céliz and Daz, 2011). Tert-butylhydroxylation of quercetin lowered its ability to scavenge free radicals but in some cases it enhanced protective effect against LDL oxidation (Lebeau et al., 2000). 3-alkyltetrahydroxyflavones with alkyl length ranging from C4 to C10 lowered lipid peroxidation and induced erythrocyte haemolysis more efficiently than initial quercetin (Filipe et al., 2009). Our team explored antioxidant activity of rutin and its derivatives esterified with fatty acids of C4-C18. We observed that this modification increased its ability to act as antioxidants in lipophilic environment (tested using Rancimat test) (Fig. 10) (Viskupičová et al., 2010).

Alkoxyl substitution of dihydroxyflavones on C5 and C6 position with alkyl chains of C5 to C10 improved their ability to inhibit 5-lipoxygenase with the corresponding $\mathrm{IC}_{50}$ value of $10 \mathrm{nM}$ (Horie et al., 1986). On the other hand 7-O-alkylation of isoflavonoids had an adverse effect to their anti-inflammatory activity (Lee et al., 1994). Among chrysin derivatives, only 5,7-diacetylflavone showed inhibitory activity against cyclooxygenase-2 $\left(\mathrm{IC}_{50}=2.7 \mu \mathrm{M}\right)$, while chrysin showed no effect (Cho et al., 2004). 
Tab. 1. Biological properties of lipophilic flavonoid derivatives.

\begin{tabular}{|c|c|c|c|}
\hline Flavonoid & Substituent & Biological effect & Reference \\
\hline $\begin{array}{l}\text { Naringin, hesperidin, neohesperidin, } \\
\text { hesperetin glucoside }\end{array}$ & Butyrate, decanoate, laurate & $\uparrow$ Antifungal & Salas et al., 2011 \\
\hline Rutin & Laurate, palmitate & $\uparrow \downarrow$ Antioxidant & Lue et al., 2010 \\
\hline $\begin{array}{l}\text { Chrysoeriol-7- } O-\beta \text {-D- }(3 "-E-p \text { - } \\
\text { coumaroyl)-glucopyranoside, } \\
\text { chrysoeriol-7-[6"'-O-acetyl- } \beta \text {-D-allosyl- } \\
(1 \rightarrow 2)-\beta \text {-D-glucopyranoside }]\end{array}$ & Vinyl laurate & $\begin{array}{l}\uparrow \text { Antioxidant, } \\
\uparrow \text { antibacterial }\end{array}$ & Mellou et al., 2005 \\
\hline Flavone, isoflavone & $\begin{array}{l}\text { Prenyl, geranyl, dimethylal- } \\
\text { lyl, methyl, methoxy }\end{array}$ & Antiproliferative & Boccard et al., 2009 \\
\hline Flavone & Geranyl & Antiproliferative & Hsu et al., 2011 \\
\hline Isorhamnetin-3-O-glucoside & Ethyl laurate, ethyl butyrate & $\begin{array}{l}\uparrow \text { Anticancer, } \\
\downarrow \text { antioxidant }\end{array}$ & Salem et al., 2011 \\
\hline Quercetin & Tert-butylhydroxy & $\uparrow \downarrow$ Antioxidant & Lebeau et al., 2000 \\
\hline Isoquercitrin & $\begin{array}{l}\text { Butyrate, caproate, caprylate, } \\
\text { decanoate, laurate, palmi- } \\
\text { tate, stearate, oleate }\end{array}$ & $\begin{array}{l}\uparrow \downarrow \text { Antioxidant, } \\
\text { } \text { anticancer }\end{array}$ & Salem et al., 2010 \\
\hline Flavane, thiaflavane & Methoxy & $\uparrow \downarrow$ Antifungal & Buzzini et al., 2008 \\
\hline Rutin, phloridzin, esculin & $\begin{array}{l}\text { Butyrate, caproate, caprylate, } \\
\text { decanoate, laurate, myristate, } \\
\text { palmitate, stearate, oleate, } \\
\text { linoleate, linolenate, } \\
\text { arachidonate, erucate }\end{array}$ & $\uparrow \downarrow$ Antiprotease & Viskupičová et al., 2011 \\
\hline Flavone & $\begin{array}{l}\text { Methylethylamine, } \\
\text { diethylamine, piperidine, } \\
\text { pyrrolidine }\end{array}$ & Neuroprotective & Sheng et al., 2009 \\
\hline Flavone & Alkyl & $\uparrow$ Anti-inflammatory & Horie et al., 1986 \\
\hline Rutin, naringin & Oleate, linolenate, linoleate & 个Anticancer & Mellou et al., 2006 \\
\hline Quercetin & Alkyl & 个Antioxidant & Filipe et al., 2009 \\
\hline Rutin & $\begin{array}{l}\text { Butyrate, caproate, capr- } \\
\text { ylate, decanoate, laurate, } \\
\text { palmitate, stearate, oleate, } \\
\text { linoleate, linolenate }\end{array}$ & 个Antioxidant & Viskupičová et al., 2010 \\
\hline Biochanin A & Alkyl & $\downarrow$ Anti-inflammatory & Lee et al., 1994 \\
\hline Flavone & Methyl, naftyl, nitro, halogen & $\uparrow$ Anticancer & Cárdenas et al., 2006 \\
\hline Chrysin & $\begin{array}{l}\text { Methoxy, dodecoxy, diacetyl, } \\
\text { methoxycinnamate }\end{array}$ & 个Anti-inflammatory & Cho et al., 2004 \\
\hline Flavone, isoflavone & Trifluoromethyl & $\downarrow$ Anticancer & Wang et al., 2005 \\
\hline Flavanone & Methoxy, benzyl & $\uparrow$ Anticancer & Yahiaoui et al., 2008 \\
\hline Flavone & $\begin{array}{l}\text { Aliphatic and heterocyclic } \\
\text { with N }\end{array}$ & $\uparrow \downarrow$ Anticancer & Liu et al., 2007 \\
\hline
\end{tabular}

Enzymatic acylation of isorhamnetin-3-O-glucoside with ethyl laurate and ethyl butyrate increased their ability to inhibit xanthine oxidase and also their antiproliferative activity against Caco-2 cells but lowered their ability to scavenge free radicals (Salem et al., 2011). Salem et al. (2010) prepared a set of isoquercitrin derivatives with different fatty acids. Modification of original skeleton resulted in improving the ability to scavenge ABTS radical, lowering the ability to scavenge DPPH radical and enhancing antiproliferative effect to colon cancer cells Caco-2.

Cárdenas et al. (2006) compared antiproliferative effect of some flavones and their derivatives. Naphtoflavons were slightly better than the initial molecules, bromo-, chloro- and nitroderivatives showed an anticancer activity substantially higher than original compounds. Trifluoromethylated derivatives of flavones and isoflavones efficiently arrested cell cycle of bone cancer cells U2OS (Wang et al., 2005). Geranyl derivatives in micromolar concentrations inhibited growth and induced apoptosis in several tested cancer cell lines (Hsu et al., 2011). Boccard et al. (2009) found that more hydrophobic flavonoids had higher affinity to P-glycoprotein, an enzyme responsible for the multidrug resistance of cancer cells towards chemotherapeutics. Chemically synthesised benzoflavanones were 7 times more effective inhibitors of aromatase than original molecules (Yahiaoui et al., 2008). Flavonoids contain- 


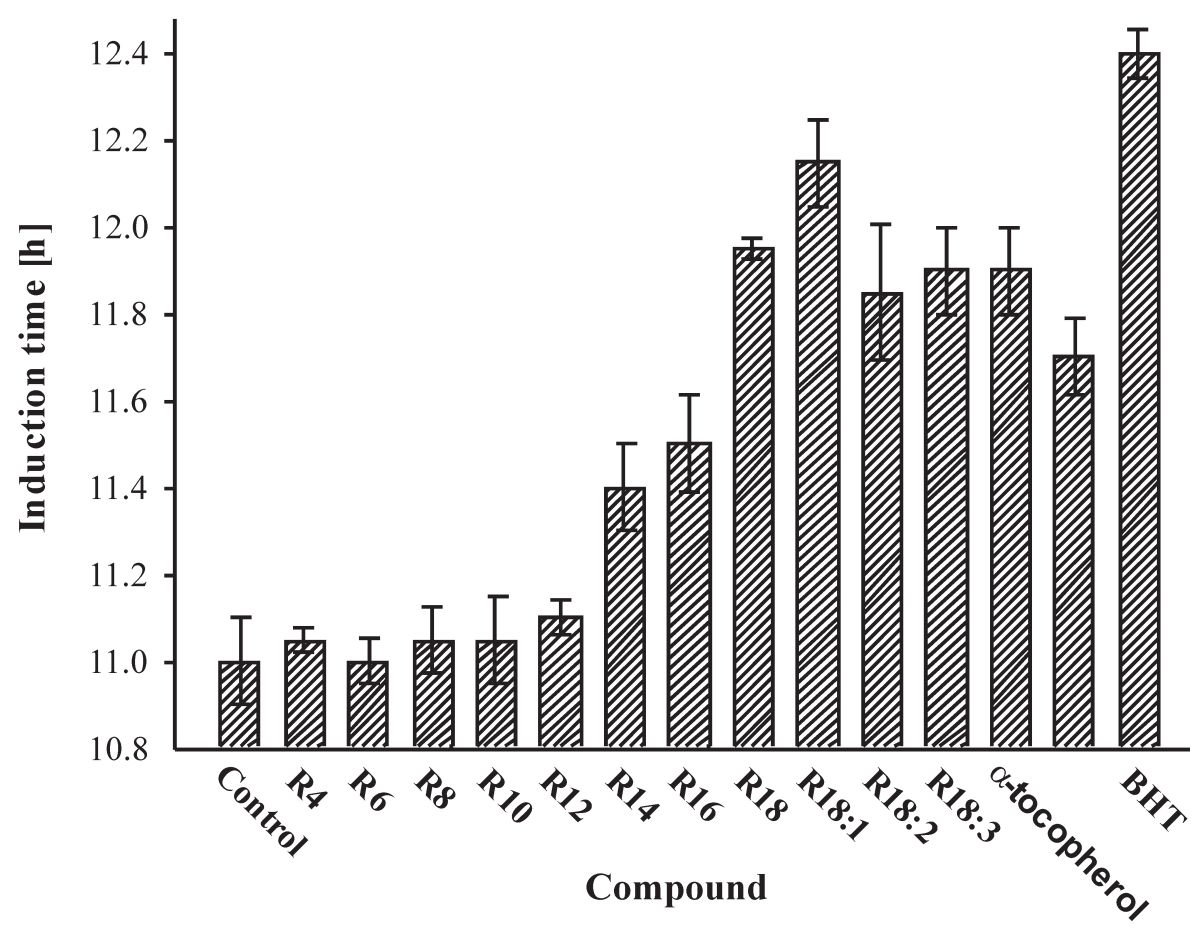

Fig. 10. Induction time values of rutin $(\mathrm{R})$ and rutin derivatives (R12-R18:3) as detected by Rancimat test (Viskupičová et al., 2010).

ing nitrogen groups significantly inhibited growth of several cancer cell lines. Among them the most effective were derivatives with dimethylamino and piperidinyl group in the position C8 on the basic skeleton (Liu et al., 2007).

Our team studied inhibitory activity of rutin, phloridzin and esculin and their lipophilic derivatives to serine proteases (trypsin, thrombin, urokinase, elastase) which are involved in some pathophysiological processes. This modification markedly increased the ability of fatty acid esters to inhibit thrombin activity (Viskupičová et al., 2011).

\section{Practical utilization of flavonoid derivatives}

There is a range of various flavonoid-containing preparations that are nowadays available in many forms in some industrial areas. These include Pycnogenol, Flavin7, Flavobion, Detralex, Ascorutin, Turmeric, creams with rutin, etc. As a guide for the preparation of their derivatives much patent literature is available. Up-to-date there are several patents oriented to the methods of preparing such derivatives as well as to their usage in food, pharmaceutical and cosmetic industry (Bombardelli and Patri, 1991; Pershadsingh and Avery, 2000; Perrier et al., 2001; Geers et al., 2003; Ghoul et al., 2006; Caldwell et al., 2009; Chung et al., 2010; Cushman et al., 2010).

\section{Food}

The main advantage of modified flavonoids in food industry lies in improving stability and solubility of initial molecules. Through acylation there are changed sensorial properties of flavonoids in foodstuffs. Degenhardt et al. (2007) found that acylation of certain flavonoids may suppress these negative taste properties in food, pharmaceutical preparations and cosmetic products for mouth hygiene.

Ghoul et al. (2006) evolved methods for the preparation of acylated flavonoid glycosides with improved stability and solubility in various food preparations, while their antioxidant activity retained unmodified or even enhanced.

Lipophilic food matrices (especially those with high content of polyunsaturated fatty acids) represent an unstableenvironment. Underatmosphericconditions they become too rapidly a subject of autooxidation. During autooxidation there are formed degradation products such as free radicals, peroxides, hydroperoxides, aldehydes and ketones that damage other food elements (proteins, vitamins, other lipids). To protect these matrices it is suitable to use lipophilic antioxidants (Perrier et al., 2001). It was found that flavonoid esters with unsaturated fatty acids prepared via enzymatic synthesis are favourable candidates for stabilisation of presented easily oxidable compounds (Mellou et al., 2006).

Caldwell et al. (2009) have patented the preparation of alkylated, alkenylated, acetylated and alkoxylated 
flavonoid derivatives. Their enhanced lipophilicity makes them effective for better protection of lipophilic food matrices; they are suitable mainly for stabilisation of food emulsions.

Another important advantage is using of acylated anthocyanins as plant pigments, that are more stable and may serve as an alternative to synthetic additives of certain type. A source of acylated anthocyanins can be radishes, red tomatoes, red cabbage etc. (Giusti and Wrolstad, 2003; Bakowska-Barczak, 2005).

Patent of Geers et al. (2003) includes the preparation of acylated flavonoid glycosides via lipase-catalysed reaction. Acylating agents are polyunsaturated fatty acids, arylaliphatic carboxylic acids, their esters and activated esters of fatty acids. One of the possible application fields of these derivatives lays in food industry, where they are useful as supplements and food additives, such as beverages for athletes, food pigments, flavouring agents etc.

\section{Pharmacy}

A disadvantage in flavonoid applications as therapeutics is their low absorption ability in gastrointestinal tract, because some of their parts underlie bacterial degradation and form complexes with compounds present in gastrointestinal tract. For purpose of enhancing their therapeutical effect, authors Bombardelli and Patri (1991) patented the preparation of flavonoid complexes with phospholipids and their usage in pharmaceutical and cosmetic preparations. With the same aim, Chung et al. (2010) published a patent for flavonoid conjugation (mainly flavanols) with polymers containing free aldehyde group.

More effective forms represent lipophilic flavonoid derivatives due to their ability to penetrate cell walls and thereby its absorption ability by dermal application is enhanced (Caldwell et al., 2006). Flavonoid lipophilization with alkyl, alkenyl, alkoxyl, alkylsulphonyl and prenyl substituents contributed to increased anticancer effects (Cushman et al., 2010).

Flavonoid dimers and their alkylated and prenylated analogues were developed to efficiently suppress multidrug resistance and to inhibit the function of P-glycoprotein that eliminate chemotherapeutics from cancer cells and thereby lower its effect (Chan and Chow, 2009).

With the aim to treat cancer and viral diseases, Joshi et al. (2011) introduced new quercetin derivatives with alkyl, alkoxyl, aryl or heterocyclic substituents. The novel compounds have changed their lipophilic-hydrophilic character and so their pharmacokinetic properties, too.

In another patent (Geers et al., 2003), a biocatalytic preparation of acylated flavonoid glycosides is described. These derivatives can be applied in pharmaceutical industry because of their ability to scavenge free radicals, inhibit diabetes development and to act as vasodilatory compounds.

Caldwell et al. (2009) reported the use of alkylated, alkenylated, acetylated and alkoxylated flavonoid derivatives for efficient prophylaxis of oncological, cardiovascular or neurological diseases. These compounds are effective antioxidants and after lipophilization they have improved bioavailability, and thus the bioactivity in the organism as well.

Esterification of kaempferol-3-O-glucoside with p-coumaric acid enhanced their anti-inflammatory activity eight times compared to initial flavonoid (Harborne and Williams, 2000).

Mellou et al. (2006) published that flavonoids esterified with polyunsaturated fatty acids lowered formation of vascular endothelial growth factor in human leukemic cells K562, whereas initial flavonoids did not show this effect. These new compounds may have, therefore, improved anti-angiogenic influence to malignant tissues and thereby anticancer effects.

For improving therapeutical effect, Pershadsingh and Avery (2000) described the preparation of lipophilic flavonoid derivatives. They used thiazolidindiones, alkyl, alkoxy, alkoxycarbonyl, aminocarbonyl and aryl groups as substituents. Such compounds show anticancer and anti-inflammatory effects, thus making them attractive in treating of metabolic and infection diseases and ophthalmological complications.

\section{Cosmetics}

The most of cosmetic and dermo-pharmaceutical preparations is based on lipid phase, where the individual components tend to oxidize, even at room temperature. Consequently, their physico-chemical and sensory properties are completely changed. Therefore, antioxidant agents that are able to protect these lipid elements are advantageously incorporated into cosmetic preparations (N'Guyen, 1995).

Flavonoids have protective and cleaning effect to skin, anti-aging properties, pigment-saving activity and supportive mechanical strength to hair (Ghoul et al., 2006). But utilization of many glycosylated flavonoids (e.g. rutin) in cosmetic formulations is limited by their low solubility in such preparations. Petersen (2007) described in his patent the preparation of nanocrystals of these compounds, whereby he achieved better solubility, stability and improved activity. This energetically difficult process could be replaced with the preparation of acylated flavonoid glycosides; thereby reaching the same result. 
Wirth et al. (2008) patented utilization of acylated flavonoid derivatives prepared via chemical synthesis into cosmetic preparations. Acylation performed on glycoside moiety of flavonoids with aromatic and aliphatic acylating agents. New compounds serve particularly as skin protectors against harmful UV radiation.

Buchholz et al. (2008) patented the preparation of conjugated acetyl, alkyl and hydroxyalkyl luteolin derivatives with cyclodextrins. This modification improved their incorporation in cosmetic preparations and simultaneously increased their stability during storage and bioavailability after application.

Carola et al. (2011) reported skin-protective effects of oxidized and alkylated flavonoid derivatives. These compounds avoid drying-out of skin and counter skin aging, which results in an improvement on the skin structure. Besides, they exert an anti-inflammatory action.

Flavonoids were also substituted with alkyl, alkenyl, acyl and alkoxyl chains, branched or unbranched, with number of carbon atoms ranging from 2 to 20. Hydrophobization of basic skeleton enhance skin-protective properties because of their easier penetration into skin cells. As a part of various preparations, they can be useful in the prevention of skin cancer, wrinkles formation and skin ageing (Caldwell et al., 2009).

Geers et al. (2003) have patented the preparation of acylated flavonoid glycosides via enzymatic synthesis. Acyl residues included polyunsaturated fatty acids, arylaliphatic carboxylic acids, their esters and activated esters of fatty acids. Presented derivatives have inhibitory activity to skin proteases, thus counteract its ageing. They also show an antioxidant effect, relieve skin, and support collagen formation. They are part of various shampoos, shower gels, creams, deodorants etc.

Moussou et al. (2007) found that esters of flavonoids with omega-substituted fatty acids (C6 to C22) were able to protect skin cells against damage by UV radiation. These flavonoid esters are more effective than flavonoids themselves.

Using alkylation and alkoxylation approach, Carola et al. (2008) modified oxidized flavonoid derivatives. They found that these compounds maintained their original antioxidant activities and thus they can be used in cosmetic preparations for skin protection against oxidative damage.

\section{Conclusion}

Flavonoids are natural low toxic substances with demonstrated numerous biological effects. This makes them interesting compounds for several ap- plication areas. Their use is however often limited by low solubility and stability in lipophilic media. A useful solution for this drawback may be the introduction of hydrophobic substances on the basic flavonoid skeleton.

Derivatization can be carried out via chemical or enzymatic approach. Lipophilization of initial flavonoids increases their solubility in lipophilic food matrices, by conferring better antioxidant protection. Hydrophobization also contributes to easier penetration of flavonoids through lipid bilayer of cell membranes, which can increase their bioavailability. Several works have shown that novel lipophilic flavonoid derivatives are more stable. It was also reported that modification of the basic structure causes an enhanced biological effects.

Lipophilic flavonoid derivatives provide a perspective substances with maintained or improved biological properties for food, cosmetic and pharmaceutical applications. Therefore, they may play an important role in the development of new drugs or food additives.

\section{Acknowledgement}

This work was supported by courtesy of The Agency of the Ministry of Education, Science, Research and Sport of the Slovak Republic for the Structural Funds of EU in the frame of the Project "Evaluation of natural substances and their selection for prevention and treatment of lifestyle diseases (ITMS 26240220040).

\section{References}

Ardhaoui M, Falcimaigne A, Engasser J-M, Moussou P, Pauly G, Ghoul M (2004) Journal of Molecular Catalysis B: Enzymatic 29: 63-67.

Bakowska-Barczak A (2005) Polish Journal of Food and Nutrition Sciences 14/55: 107-116.

Birbara PJ (2011) Patent WO 2011049629.

Boccard J, Bajot F, Di Pietro A, Rudaz S, Boumendjel A, Nicolle E, Carrupt P-A (2009) European Journal of Pharmaceutical Sciences 36: 254-264.

Bombardelli E, Patri GF (1991) Patent US 5043323.

Bridson JH (2007) Derivatisation of polyphenols: thesis. New Zealand: The University of Waikato.

Buchholz H, Rosskopf R, Carola Ch (2008) Patent US 20080045478.

Buzzini P, Menichetti S, Pagliuca Ch, Viglianisi C, Branda E, Turchetti B (2008) Bioorganic \& Medicinal Chemistry Letters 18: 3731-3733.

Caballero B (2009) Guide to nutritional supplements. Elsevier, Oxford.

Caldwell ST, Bennett ChJ, Hartley RCh, McPhail DB, Duthie GG (2006) Patent US 20060137207.

Caldwell ST, Bennett ChJ, Hartley RCh, McPhail DB, Duthie GG (2009) Patent US 7601754.

Carola Ch, Huber S, Buchholz H (2008) Patent US 20080319050. 
Carola Ch, Huber S, Buchholz H (2011) Patent US 7867993.

Cárdenas M, Marder M, Blank VC, Roquin LP (2006) Bioorganic \& Medicinal Chemistry 14: 2966-2971.

Céliz G, Daz M (2011) Process Biochemistry 46: 94-100.

Cushman MS, Pezzuto JM, Maiti A (2010) Patent US 20100099755

Danieli B, De Bellis P, Carrea G, Riva S (1990) Helvetica Chimica Acta 73: 1837-1844.

Degenhardt A, Ulrich F, Hofmann T, Stark T (2007) Patent US 20070269570.

Filipe P, Silva AM, Seixas RS, Pinto DC, Santos A, Patterson LK, Silva JN, Cavaleiro JA, Freitas JP, Mazière JC, Santus R, Morlière P (2009) Biochemical Pharmacology 77: 957-964.

Gao C, Mayon P, MacManus DA, Vulfson EN (2001) Biotechnology and Bioengineering 71: 235-243.

Geers B, Otto R, Weiss A, Petersohn D, Schroeder KR, Schlotmann K (2003) Patent US 20030170186.

Ghoul M, Engasser J-M, Moussou P, Pauly G, Ardhaoui M, Falcimaigne A (2006) Patent US 20060115880.

Giusti MM, Wrolstad RE (2003) Biochemical Engineering Journal 14: 217-225.

Harborne JB, Williams CA (2000) Phytochemistry 55: 481-504.

Hertog MG, Feskens EJ, Hollman PC, Katan MB, Kromhout D (1993) The Lancet 342: 1007-1011.

Horie T, Tsukayama M, Kourai H, Yokoyama C, Furukawa M, Yoshimoto T, Yamamoto S, Watanabe-Kohno S, Ohata K (1986) Journal of Medicinal Chemistry 29: 2256-2262.

Hsu Ch-L, Shyu M-H, Lin J-A, Yen G-Ch, Fang S-Ch (2011) Food Chemistry 127: 127-134.

Chan T-H, Chow LM-Ch (2009) Patent US 20090197943.

Chebil L, Humeau C, Falcimaigne A, Engasser J-M, Ghoul M (2006) Process Biochemistry 41: 2237-2251.

Cho H, Yun Ch-W, Park W-K, Kong J-Y, Kim KS, Park Y, Lee S, Kim B-K (2004) Pharmacological Research 49: $37-43$.

Chung JE, Kurisawa M, Yang YY, Lang Z (2010) Patent US 20080102052.

Joshi NS, Aggarwal P, Hirpara VK, Jaggi M, Singh A, Awasthi A, Verma R (2011) Patent US 20110034413.

Knekt P, Järvinen R, Seppänen R, Heliövaara M, Teppo L, Pukkala E, Aromaa A (1997) American Journal of Epidemiology 146: 223-230.

Knekt P, Kumpulainen J, Järvinen R, Rissanen H, Heliövaara M, Reunanen A, Hakulinen T, Aromaa A (2002) The American Journal of Clinical Nutrition 76: 560-568.

Kontogianni A, Skouridou V, Sereti V, Stamatis H, Kolisis FN (2003) Journal of Molecular Catalysis B: Enzymatic 21: 59-62.

Kukhareva TS, Krasnova VA, Koroteev MP, Kaziev GZ, Kuleshova LN, Korlyukov AA, Antipin MY, Nifantev EE (2004) Russian Journal of Organic Chemistry 40: $1190-1193$.

Kyle JAM, Sharp L, Little J, Duthie GG, McNeill G (2010) British Journal of Nutrition 103: 429-436.

Lebeau J, Furman C, Bernier JL, Duriez P, Teissier E, Cotelle N (2000) Free Radical Biology \& Medicine 29: 900-912.

Lee SJ, Baek HJ, Lee ChH, Kim HP (1994) Archives of Pharmacal Research 17: 31-35.
Li N-G, Shi Z-H, Tang Y-P, Yang J-P, Duan J-A (2009) Beilstein Journal of Organic Chemistry 5: 60.

Liu T, Xu Z, He Q, Chen Y, Yang B, Hu Y (2007) Bioorganic \& Medicinal Chemistry Letters 17: 278-281.

Lue B-M, Nielsen NS, Jacobsen Ch, Hellgren L, Guo Z, Xu X (2010) Food Chemistry 123: 221-230.

Lugasi A, Hóvári J, Sági KV, Bíró L (2003) Acta Biologica Szegediensis 47: 119-125.

Materska M (2008) Polish Journal of Food and Nutrition Sciences 58: 407-413.

Mattarei A, Biasutto L, Rastrelli F, Garbisa S, Marotta E, Zoratti M, Paradisi C (2010) Molecules 15: 4722-4736.

McCabe RW, Rodger A, Taylor A (2005) Enzyme and Microbial Technology 36: 70-74.

Mellou F, Lazari D, Skaltsa H, Tselepis AD, Kolisis FN, Stamatis H (2005) Journal of Biotechnology 116: 295-304.

Mellou F, Loutrari H, Stamatis H, Roussos Ch, Kolisis FN (2006) Process Biochemistry 41: 2029-2034.

Mink PJ, Scrafford CG, Barraj LM, Harnack L, Hong CP, Nettleton JA, Jacobs DR Jr. (2007) The American Journal of Clinical Nutrition 85: 895-909.

Moussou P, Falcimaigne A, Ghoul M, Danoux L, Pauly G (2007) Patent US 20070184098.

Mudnic I, Modun D, Rastija V, Vukovic J, Brizic I, Katalinic V, Kozina B, Medic-Saric M, Boban M (2010) Food Chemistry 119: 1205-1210.

N'Guyen QL (1995) Patent US 5431912.

Passicos E, Santarelli X, Coulon D (2004) Biotechnology Letters 26: 1073-1076.

Perrier E, Mariotte A-M, Boumendjel A, Bresson-Rival D (2001) Patent US 20016235294.

Pershadsingh HA, Avery MA (2000) Patent US 6028088.

Petersen R (2007) Patent EP 2007009943.

Prasain JK, Carlson SH, Wyss JM (2010) Maturitas 66: 163-171.

Rice-Evans CA, Miller NJ, Paganga G (1996) Free Radical Biology \& Medicine 20: 933-956.

Robards K, Antolovich M (1997) Analyst 122: 11R-34R.

Salas MP, Celiz G, Geronazzo H, Daz M, Resnik SL (2011) Food Chemistry 124: 1411-1415.

Salem JH, Humeau C, Chevalot I, Harscoat-Schiavo Ch, Vanderesse R, Blanchard F, Fick M (2010) Process Biochemistry 45: 382-389.

Salem JH, Chevalot I, Harscoat-Schiavo Ch, Paris C, Fick M, Humeau C (2011) Food Chemistry 124: 486-494.

Sheng R, Lin X, Zhang J, Chol KS, Huang W, Yang B, He Q, Hu Y (2009) Bioorganic \& Medicinal Chemistry 17: 6692-6698.

van Aardt TG, van Heerden PS, Ferreira D (1998) Tetrahedron Letters 39: 3881-3884.

Viskupičová J, Ondrejovič M, Šturdík E (2008) Journal of Food and Nutrition Research 47: 151-162.

Viskupičová J, Ondrejovič M, Šturdík E (2009a) Pharmazie 64: 355-360.

Viskupičová J, Ondrejovič M, Sturdík E (2009b) Acta Chimica Slovaca 2: 88-106.

Viskupičová J, Strosova M, Šturdík E, Horáková L (2009c) Neuroendocrinology Letters 30: 148-151.

Viskupičová J, Danihelová M, Ondrejovič M, Liptaj T, Šturdík E (2010) Food Chemistry 123: 45-50. 
Viskupičová J, Danihelová M, Májeková M, Liptaj T, Šturdík E (2011) Journal of Enzyme Inhibition and Medicinal Chemistry, in press.

Vorsa N, Vvedenskaya IO, Huang M-T, Rosen LRSL (2007) Patent US 7270837.

Wang C-L, Li H-Q, Meng W-D, Qing F-L (2005) Bioorganic \& Medicinal Chemistry Letters 15: 4456-4458.
Wirth C, Buchholz H, Carola Ch (2008) Patent US 20080199414.

Yahiaoui S, Fagnere C, Pouget Ch, Buxeraud J, Chulia A-J (2008) Bioorganic \& Medicinal Chemistry 16: 1474-1480.

Yao LH, Jiang YM, Shi J, Tomás-Barberán SA, Datta N, Singanusong R, Chen SS (2004) Plant Foods for Human Nutrition 59: 113-122. 